\title{
Bank Responses to Corporate Reorganization: Evidence from an Emerging Economy
}

Mariana Oreng ${ }^{1}$

Richard Saito ${ }^{1}$

Vinicius A. B. Silva ${ }^{2}$

Fundação Getulio Vargas, São Paulo, SP, Brazil ${ }^{1}$ Fundação Escola de Comércio Álvares Penteado, São Paulo, SP, Brazil ${ }^{2}$

Received 9 May 2018. This paper was with the authors for three revisions. Accepted 22 March 2019. First published online 12 April 2019.

Rosilene Marcon was the associate editor for this article.

Editorial assistant: Luciane Kato Kiwara

Editor-in-chief: Carlo Gabriel Porto Bellini 


\section{Abstract}

This study analyzes a unique dataset of 125 corporate reorganization filings in Brazil from 2006 to 2016 to understand the role of bank creditor seniority in bankruptcy outcomes of small- and medium-sized companies. We find that conflict between bank creditor classes is relevant for explaining reorganization outcomes and that it occurs when organizations are in the money. Additionally, bank seniority matters more than the bank's debt share for explaining bankruptcy outcomes in creditor-oriented regimes. Finally, we find a concave relationship between favorable votes and the number of banks involved and between favorable votes and a company's age.

Key words: bankruptcy; reorganization; conflict between creditors; creditors' bargain model. 


\section{Introduction}

According to Jackson (1982), most of the bankruptcy process concerns creditor distribution questions rather than discharge of the debtor. Along these lines, reaching a common agreement between creditors and debtors is crucial to reorganization filings. Because banks and secured institutional lenders are those creditors who are typically able to influence corporate policies (Bae \& Goyal, 2009; James, 1995), our goal is to assess the role of financial creditors during corporate reorganizations. While some studies have focused on the conflict between debtors and representative creditors (Bebchuck, 2002) and the resolution of disputes between creditors (Gilson, Hotchkiss, \& Ruback, 2000), this paper investigates how banks (as both secured and unsecured creditors) vote on the reorganization plans of firms that exhibit a higher degree of information asymmetry than large and public companies. To our knowledge, there is a shortage of explanations for the behavior of senior and junior banks during corporate reorganization processes of medium and small companies. Therefore, the question under investigation is how do bank creditors with different seniorities vote on corporate reorganization filings of small and medium companies? Our secondary question is related to the association between creditor conflict and reorganization outcomes.

This study adds to the bankruptcy literature by offering important insights into the creditors' bargain model and by analyzing a unique dataset that was not previously available and that contains bankruptcy court documents from 125 corporate reorganization filings in Brazil from 2006 to 2016. First, we shed light on the association between bank creditors' decisions and the reorganization outcomes of smaller and medium companies (SMEs) that exhibit a higher level of information asymmetry. This analysis is relevant in the context of emerging economies, where SMEs' financial statements often exhibit a higher level of opacity and where companies rely more on bank debt than on capital market instruments. While evidence of reorganization issues for public companies with a diverse pool of creditors (Franks \& Sussman, 2005) abounds for both emerging (Claessens, Djankov, \& Klapper, 2003) and developed economies (Brunner \& Kahnen, 2008; Westbrook, 2015), deeper analysis for SMEs in creditor-oriented bankruptcy regimes is still in progress (Franken, 2004). Our study is an opportunity to fill this gap. Second, while most studies begin by assuming that senior creditors exert strong control over the reorganization process (Ayotte \& Morrison, 2009; Branch \& Ray, 2007), we take a step back to understand which factors are associated with conflicting decisions by banks with different seniorities and by analyzing the decisions from the point of view of real options (Baird \& Morisson, 2001).

Following the trend in the finance literature, this study is a hybrid between law and financial distress issues. We focused on the descriptive statistics of the data collected and performed parametric and nonparametric average tests to understand the role of the conflict between bank creditors in the final outcome of reorganizations. We also use logit and probit specifications to understand which factors are associated with creditors voting in favor of a reorganization.

Collectively, our analysis demonstrates that conflict between bank creditor classes is positively associated with the proportion of senior bank debt and the proportion of labor debt. Contract terms also seem to be highly correlated with disagreements between bank creditors: in cases of 
conflict, the debt of senior bank creditors received higher interest rates, and these creditors had to wait 3 times longer before receiving any payment. In this sense, our results corroborate the idea that senior creditors have come to dominate the reorganization process. Logit and probit specifications provide evidence of a coordination problem between creditors, in accordance with the literature: we find a concave relationship between favorable votes and the number of bank creditors involved in a reorganization and between favorable votes and a company's age. This indicates that when considering the number of banks involved, the likelihood of a bank voting in favor of a reorganization rises at decreasing rates. Moreover, although banks will favor the reorganization of older companies, this isn't necessarily true for the ones that have existed for too long and thus might not be able to reorganize in a proper manner due to bad management or lack of technologies, for instance, where creditors would be better off when they are liquidated.

This research is timely for a variety of reasons. First, recent bankruptcy studies have shifted the focus away from equity and managerial control to creditor behavior. These studies demonstrate that senior lenders use several strategies to limit the bargaining position of subordinated debt holders during reorganizations (Ayotte \& Morrison, 2009; Branch \& Ray, 2007), which reinforces the need to study the conflicts between creditor classes. Second, the number of corporate reorganization filings in Brazil increased from 252 to 828 between 2006 and 2014, which amounts to an increase of approximately $14 \%$ per year. In 2015, due to Brazil's economic crisis, this number has jumped to 1287 , which represents an increase of $55 \%$ in only one year. The peak of requests occurred in 2016, as companies still faced two main negative impacts of the Brazilian economic recession: the lower inflow of cash and increasingly expensive debt, making it difficult to finance and renegotiate debts (Copetti, 2017). Although some practitioners argue that some of these filings are only precautionary measures, the increase was significant. Figure 1 demonstrates that the Brazilian services sector suffered the most, with the highest increase in reorganization filings, followed by retail.

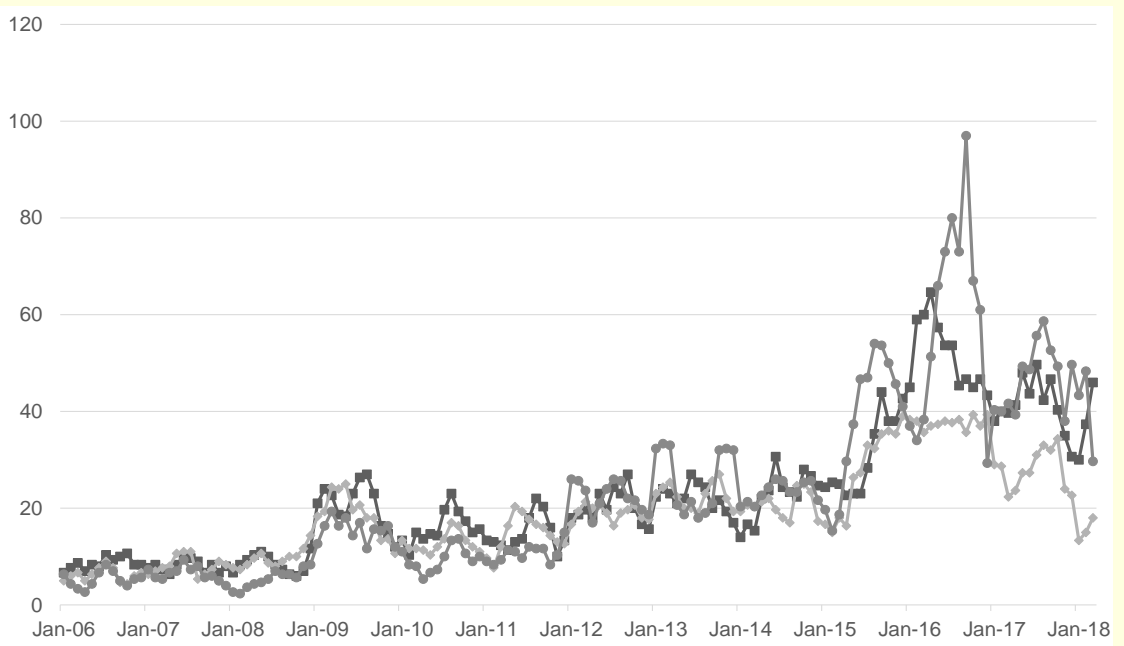

Figure 1. Reorganization filings in Brazil by sector

Source: Elaborated by the authors. 
The paper proceeds as follows: the next section reviews the previous literature. Data analysis and the role of conflict between bank creditor classes is presented in the third session. The fourth session covers our cluster analysis and logistic regression results. The conclusion and references follow.

\section{Prior Literature}

Many authors argue that reorganization is a two-stage game (Bulow \& Shoven, 1978; Fama, 1985; Fisher \& Martel, 1995; White, 1981). In the first stage, firms decide whether to file for reorganization. Once a reorganization procedure is chosen over liquidation, "there is a conflict between the secured creditors' right to claim their collateral versus the goal of reorganizing the firm" (Araujo \& Funchal, 2005, p. 4). In the second stage, creditors bargain and vote in favor or against the reorganization.

We identified several approaches in the literature to modeling creditor responses to corporate reorganizations. Some studies view the bargaining between creditors as a noncooperative game (Annabi, Breton, \& Français, 2012), while others argue that this process can be depicted as a collective action problem or as a larger-scale prisoner's dilemma (Fan \& Sundaresan, 2000; Jackson, 1982; Li \& Li, 1999). Another study addresses the bankruptcy decision as the exercise of a real option, as claimholders have incentives to withhold information due to the process length (Baird \& Morisson, 2001). The conflict of interest lies in the fact that when a company files for bankruptcy, its market value is lower than the total amount of its debt. Hence, the creditors know that their best interest will be maximized as long as they cooperate. Moreover, covering all aspects of negotiations, such as the future use of the firm's assets or how much and what type of securities the various creditors will receive, can result in a lengthy and costly procedure (Hotchkiss, John, Mooradian, \& Thorburn 2008).

Even though bankruptcy law is designed to avoid coordination problems and contract incompleteness, Jackson (1982) argues that "bankruptcy law's beguiling slogan has been little more than a banal reminder that equals are to be treated equally in bankruptcy: the important determination of who those equals are is often not resolved under bankruptcy law" (p. 860). According to the author, "a more profitable line of pursuit might be to view bankruptcy as a system designed to mirror the agreement one would expect the creditors to form among themselves were they able to negotiate such an agreement from an ex ante position" (p. 860). Thus, in his view, bankruptcy proceedings are at the back end of the creditors' bargain model. In fact, several studies have demonstrated that deviations from the absolute priority rule occur in practice (Eberhart, Moore, \& Roenfeldt, 1990; Franks \& Torous, 1989; Weiss, 1990). In Germany, a financial institution is appointed to mitigate the risk of uncoordinated creditor action (Bankenpool). However, we find no documentation of such an instrument in Brazil or the United States. In this sense, bank creditors' bargaining is a coordination problem (Brunner \& Kahnen, 2008).

Branch and Ray (2007) argue that subordinate debtholders have considerable leverage in the bankruptcy negotiation process due to courts' bias toward obtaining consensual plans and their 
ability to block or delay confirmation of a plan that provides subordinate debtholders with little or no recovery. Secured debtholders, on the other hand, can obtain a recovery in liquidation, which provides nothing for junior creditors. Even though bankruptcy laws are written in such a way that the Absolute Priority Rule should not be violated, senior creditors can use several strategies to limit the bargaining position of junior creditors, such as vote dilution, the enforcement of indenture provisions or by exercising control through stringent covenants. This bargaining between secured and unsecured creditors can distort the reorganization process. Ayotte and Morrison (2009) argue that creditors with senior, secured claims have come to dominate the Chapter 11 process. These recent findings are contrary to Welch (1997), who proposes that bank debt is universally senior, because if the banks were unsecured, they would be better organized and could more strongly contest priority in cases of financial distress.

Studying how bank creditors behave during the reorganization process is useful for several reasons. First, companies do not rely on public issuance in some countries because their bond markets are stunted, making bank financing more important (Allen, Chui, \& Maddaloni, 2008). In this regard, Franken (2004) highlights the importance of making a distinction between debtororiented bankruptcy regimes such as those in the United States and creditor-oriented ones such as those in Europe. The author highlights that the governance structure of SMEs with concentrated secured bank lenders (which falls in the second category) suggests that different optimal regimes may exist for different types of firms.

Second, some articles highlight the potential problems faced by distressed firms that have bank debt because banks can not only create regulatory difficulties to scale down the firms' claims but can also be more difficult to obtain concessions from (James, 1995). Asquith, Gertner and Scharfstein (1994) also argue that banks do not play much of a role in resolving financial distress, and real debt relief comes from subordinated creditors. The authors, however, rely on the same assumption made by Welch, namely that banks are predominantly senior and thus have an advantage in these negotiations.

Third, some studies provide evidence that banks and secured institutional lenders are the creditors who are usually able to influence corporate policies, rather than public bondholders or trade creditors (Gilson \& Veytsupens, 1994). Finally, because firms usually have more than one bank as a creditor, one stream of literature highlights the issue of the size of the group of creditors and their role in a reorganization as a whole: Brunner and Krahnen (2008) demonstrate that while coordination among a smaller group of banks is associated with a higher probability of reorganization success, the opposite holds for an increased number of bank lenders because inefficiencies arise from the inability to renegotiate multiple debts. Franks and Sussman (2005), for their part, argue that debt dispersion can lead to coordination failures.

On the one hand, Chen, Weston and Altman (1995) hypothesize that when there is a group of bank-type lenders, the parties will function according to a Coase Theorem [1937], which holds that they will work as one party seeking to maximize investment returns in their joint interest. Here, we understand that an agreement between parties implies an efficiency gain because it involves lower financial distress costs, as proposed by Bebchuk and Chang (1992). Thus, one 
should expect banks to display the same voting profile during creditors' meetings. Kirschbaum (2009), on the other hand, argues that secured creditors will usually prefer to value the assets of a corporation being reorganized at something close to an amount that is sufficient to cover their own claims, without regard for other parties, which would make one assume that secured creditors do not necessarily cooperate. Gertner and Scharfstein (1991), for their part, offer a theoretical explanation for the mixed positions in the literature: when financial distress hampers operating performance, financial renegotiation is inefficient and the Coase Theorem fails. In this sense, one should expect unsuccessful reorganizations to be related to diminished coordination among lenders. We will address this debate empirically.

Bank behavior is a topic that is subject to considerable controversy, and the recent literature on bankruptcy has shifted the focus away from equity and managerial control and demonstrated that the unified, single-creditor framework is far from universal. Conflict therefore occurs because of the fundamental inefficiency of the bankruptcy process: resource allocation questions (sell versus reorganize) are ultimately confounded with distributional questions (how much each creditor will receive) (Ayotte \& Morrison, 2009).

\section{Corporate reorganization process in Brazil}

Bankruptcy proceedings have two possible outcomes: reorganization or liquidation. Corporate reorganization is a legal tool to avoid bankruptcy and a shield with respect to the company's payment obligations. In the United States, these mechanisms are referred to as Chapter 11 and Chapter 7 of the US bankruptcy code, respectively. In Brazil, the process is fairly similar and is coded in the Bankruptcy Code of 2005. In comparison to the previous Brazilian code, it "offers more transparency in terms of procedures and offers stakeholders more control of the process. It also allows unsuccessful companies to regain credibility and reorganize their activities" (Ministério da Justiça, 2011). According to Article 50 of the Brazilian Bankruptcy Code (Lei n. 11.101, 2005), firms have at their disposal a total of 15 tools to structure a reorganization process. These tools are not exclusive and can be pursued at the same time.

The Brazilian government is reviewing this code, arguing that the intention is to aid in the recovery of productivity and sustain job positions as the country faces a severe stagnation scenario. Even though we had access to only a few balance sheet figures from the companies we covered, we verify that the most important issue seems to be mismanagement and not problems with the law itself. Indeed, most of the filings come from small enterprises.

According to the deadlines established by the Brazilian Bankruptcy Code of 2005, from the approval and beginning of the implementation of a reorganization plan, a company has up to 2 years to negotiate and settle its liabilities. Similarly, in the United States, the average Chapter 11 reorganization case takes 25 months to confirm the reorganization (Branch \& Ray, 2007). For more information about the determinants of delays in corporate reorganizations, see Silva (2015). To decide whether a company is subject to reorganization or liquidation, creditors attend creditors' meetings. 


\section{Data Analysis}

\section{Data sources}

Our main sources of data are corporate reorganization filings, judicial trustees' websites and files from one of the main Brazilian courts (Vara de Falências e Recuperação Judicial de São Paulo). Our initial sample had more than 140 cases, but because of missing information, we discarded 15 of them; thus, our final sample contains information on 125 corporate reorganizations in Brazil from 2006 to 2016. For each case, we analyze the following documents: list of creditors, creditors' meeting minutes, corporate reorganization plans and modified plans, and reports of the valuation of assets.

Although the amount of reorganization filings in Brazil is much higher than the number in our sample, Brazil lacks data centralization. Some documents can be found at state courts, and filing companies and consulting firms often do not provide such documents on their websites. Despite this challenge, our sample contains reorganization filings from 10 different states, but contains a heavier weight from the southern and southeastern regions ( $41 \%$ of the companies are from São Paulo, the biggest Brazilian state in economic terms; $19 \%$ are from Rio Grande do Sul; 13\% are from Santa Catarina; and 11\% are from Goiás). The entire process in Brazil from registration to approval or rejection can take up to two years, which is why some recent cases might be missing in our dataset.

For the cases in which the proposed conditions were different for different banks, we noted in our files the highest bank haircut as well as the longest waiting period. In cases of foreign debt in US dollars, we used the exchange rate for the month of the approval or rejection of the plan to convert the figures to Brazilian Reais. As we lacked financial statement figures, we also collected information on residual book values and used it as our measure of asset valuation.

For each case, we gathered the following information for both the secured and unsecured classes: readjustment index, interest rate, proposed haircut, and amortization and waiting period. Because our interest lies in role of the financial institutions, we detailed each bank's credits and behavior during the creditors' meetings. In this sense, we typified bank behavior through 10 different possible interventions (Table 1). To include the dimensions of a company's size and its financial health, we collected data on the residual book values as reported in the reorganization plans and estimated by the consulting companies that prepared the legal documents. 
Table 1

Bank creditors' interventions during creditors' meetings

\begin{tabular}{|c|c|}
\hline Code & Bank intervention \\
\hline 0 & $\begin{array}{l}\text { No Intervention / Bank did not hand in required documents on time / Bank arrived late to the Committee / Bank was } \\
\text { absent }\end{array}$ \\
\hline 1 & $\begin{array}{l}\text { Bank did not agree with listed credit or credit classification or presented a Challenge procedure. In Portuguese, this } \\
\text { is called Impugnação de crédito }\end{array}$ \\
\hline 2 & Bank requested a longer period for analysis or requested Meeting suspension \\
\hline 3 & Bank requested conditions other than those presented by the company or presented an Alternative plan \\
\hline 4 & Bank assigned receivables to a Receivables investment fund \\
\hline 5 & $\begin{array}{l}\text { Bank requested that guarantees not be suspended or that it will maintain execution against guarantors or co- } \\
\text { obligors, as a creditor is defined as a person or entity who promises to pay back a loan if the original borrower does } \\
\text { not pay it back, and a co-obligor is defined as one who is bound together with one or more others to fulfill an } \\
\text { obligation }\end{array}$ \\
\hline 6 & Unsecured Bank did not agree with conditions proposed to Secured banks or vice-versa \\
\hline 7 & Bank did not agree with Reorganization request or stated that proposed Plan lacks legal certainty \\
\hline 8 & Bank stated that it has Priority credit. In Portuguese, this is called Crédito extraconcursal \\
\hline 9 & Bank did not agree with conditions proposed to Banks in the same group \\
\hline 10 & Bank was against sale of fixed assets \\
\hline
\end{tabular}

\section{Descriptive statistics}

General descriptive statistics are presented in Table 2 . On average, firms had a total of $\mathrm{R} \$ 128$ million in debt, and bank debt represented $55 \%$ of this amount, or $\mathrm{R} \$ 71$ million. Including both bank and nonbank debt, secured debt was approximately $\mathrm{R} \$ 13$ million, and average unsecured debt was approximately $\mathrm{R} \$ 98$ million. Companies had an average life of 32 years, and the average haircut proposed for the creditors was $43 \%$.

Table 2

\section{Descriptive statistics - general}

\begin{tabular}{lcccccccc}
\hline In BRL millions & $\begin{array}{l}\text { Total } \\
\text { debt }\end{array}$ & $\begin{array}{l}\text { Senior } \\
\text { debt }\end{array}$ & $\begin{array}{l}\text { Junior } \\
\text { debt }\end{array}$ & $\begin{array}{l}\text { Labor } \\
\text { debt }\end{array}$ & $\begin{array}{l}\text { Asset } \\
\text { valuation }\end{array}$ & $\begin{array}{l}\text { Haircut } \\
\text { (senior } \\
\text { debt) }\end{array}$ & $\begin{array}{l}\text { Haircut } \\
\text { (junior } \\
\text { debt) }\end{array}$ & Age \\
\hline n. obs & 114 & 74 & 110 & 114 & 58 & 39 & 78 & 109 \\
Average & 127.9 & 13.9 & 98.056 & 1.9 & 319.8 & $42 \%$ & $45 \%$ & 32 \\
St. dev & 336.6 & 37 & 281.9 & 4.9 & 1,068 & $23 \%$ & $23 \%$ & 23 \\
Max & 2,325 & 204.5 & 2,012 & 51.6 & 4,426 & $90 \%$ & $85 \%$ & 113 \\
Min & 0.4 & 0 & 0 & 0 & 0,1 & $0 \%$ & $0 \%$ & 1 \\
\hline
\end{tabular}

To understand the correlation between variables, we calculated both linear and Kendall-tau correlations (Tables 3 and 4). Some statistics are worth emphasizing. First, the correlation between the debt-to-asset ratio and the haircut ratio is $25.09 \%$, indicating that the haircut was higher in the case of more indebted companies. Second, the age of a company is negatively 
correlated with the haircut ratio and the debt-to-asset ratio. This means that, on average, older companies were less indebted. Kendall-tau results also suggest a positive relationship between the number of bank creditors involved in a reorganization filing and the debt-to-asset ratio, which in cases of more indebted companies also involves more banks.

Table 3

\section{Correlation matrix}

\begin{tabular}{|c|c|c|c|c|c|c|}
\hline & Vote & $\begin{array}{l}\text { haircut_senior_j } \\
\text { unior }\end{array}$ & qtybanks & In_debt_asset & In_age & $\begin{array}{l}\text { debtbank_asset } \\
\text { ratio }\end{array}$ \\
\hline Vote & 1 & & & & & \\
\hline \multirow[t]{2}{*}{ haircut_senior_junior } & 0.0057 & 1 & & & & \\
\hline & 0.9307 & & & & & \\
\hline \multirow[t]{2}{*}{ qtybanks } & -0.013 & 0.0451 & 1 & & & \\
\hline & 0.7116 & 0.5063 & & & & \\
\hline \multirow[t]{2}{*}{ In_debt_asset } & -0.1354 & 0.2509 & -0.2433 & 1 & & \\
\hline & 0.0087 & 0.0074 & 0 & & & \\
\hline \multirow[t]{2}{*}{ In_age } & 0.0768 & -0.2872 & 0.0858 & -0.2786 & 1 & \\
\hline & 0.0412 & 0.0002 & 0.0236 & 0 & & \\
\hline \multirow[t]{2}{*}{ debtbank_asset_ratio } & 0.0281 & -0.0104 & 0.0135 & -0.2028 & -0.0618 & 1 \\
\hline & 0.5874 & 0.9225 & 0.7943 & 0.0042 & 0.2582 & \\
\hline
\end{tabular}

Note. In this table, the first row describes the coefficients, and the second row describes the significance level.

Table 4

Kendall-tau correlation matrix

\begin{tabular}{|c|c|c|c|c|c|c|}
\hline & Vote & haircut_senior_junior & In_qtybanks & In_debt_asset & In_age & debtbank_asset_ratio \\
\hline Vote & 0.4381 & & & & & \\
\hline haircut_senior_junior & 0.0356 & 0.3143 & & & & \\
\hline In_qtybanks & 0.1568 & 0.1271 & 0.8339 & & & \\
\hline In_debt_asset & -0.0095 & 0.1749 & 0.3077 & 0.932 & & \\
\hline In_age & 0.0749 & -0.0687 & 0.1032 & -0.2709 & 0.8976 & \\
\hline debtbank_asset_ratio & 0.0119 & 0.0785 & -0.1571 & -0.2107 & 0.0751 & 1 \\
\hline
\end{tabular}

Regarding bank debt (Table 5), there were approximately 9 bank creditors in each case. Each bank had an average of $\mathrm{R} \$ 8$ million in secured debt and $\mathrm{R} \$ 20$ million in unsecured debt. On average, bank debt represented 55\% of the companies' total debt. For both approved and rejected cases, the proportion of unsecured debt to companies' total debt was higher than the proportion of secured debt. Additionally, rejected cases had more secured debt than the approved cases (28.54\% versus $16.29 \%$ ). These findings suggest that the presence of secured debt creates challenges for the approval of the plan due to the negotiating power of the secured banks, which 
usually apply pressure for better conditions (large banks made two-thirds of the requests for better debt terms). Large banks had unsecured debt in $86 \%$ of our cases and secured debt in $40 \%$ of the cases, with an average value of $\mathrm{R} \$ 12.8$ million and $\mathrm{R} \$ 3.48$ million, respectively. However, if we exclude HSBC, average unsecured bank debt decreases to $\mathrm{R} \$ 4$ million. Contrary to our expectations, in only $5 \%$ of the cases is the Brazilian Development Bank (BNDES) the creditor, with an average amount of $\mathrm{R} \$ 37.8$ million. This may be because the largest proportion of reorganization filings during the period we cover comes from small companies.

Table 5

Descriptive statistics - bank debt

\begin{tabular}{lcccc}
\hline In BRL millions & Bank debt & Bank senior debt (per bank) & Bank junior debt (per bank) & \# Banks \\
\hline n. obs & 124 & 113 & 123 & 125 \\
Average & 71.4 & 7.9 & 19.9 & 9 \\
st. dev & 251.2 & 20.6 & 311.3 & 5 \\
Max & 2,262 & 130.8 & 8,291 & 24 \\
Min & 0 & 0 & 0 & 1 \\
\hline
\end{tabular}

To contrast our findings with those of Brunner and Kahnen (2008), we also compare the number of banks involved in a certain case and the plan approval rate. Our sample contains 108 banks. For the entire sample, each bank acted as a creditor in an average of 5 bankruptcy procedures. If we consider only the six largest banks in Brazil (Banco do Brasil, Bradesco, Caixa Econômica Federal, HSBC, Itaú and Santander), this number increases to 52. The correlation between the number of junior banks involved and the approval rate is minus seventeen percent $(-17 \%)$. For senior banks, the number is similar, at minus fourteen percent $(-14 \%)$. This result is in accordance with Brunner and Kahnen's (2008) findings: the more banks that are involved in a reorganization case, the more likely the reorganization is to be rejected by the creditors. The average number of bank creditors is slightly higher for cases involving conflict (8 versus 5). Banco do Brasil and Itaú (two of the six largest banks in Brazil) are creditors in $80 \%$ of the conflict cases, while they are creditors in only $57 \%$ of the total cases for the entire sample. Bank creditors requested that guarantees should be maintained $14 \%$ of the time, while we verified only half of this frequency for the entire sample.

Although practitioners argue that labor debt poses challenges for the negotiation of reorganizations, in our cases, labor debt represented only $1 \%$ of total debt. Even though workers have priority in payment according to the Brazilian bankruptcy code, this amount does not seem to represent a large fraction of the total pie. Indeed, there were only 2 cases in our sample in which workers voted against the reorganization plan.

Practitioners in Brazil also argue that some companies have been using the reorganization process as a means to improve their bargaining positions with both suppliers and debtholders and not necessarily because of financial distress. Indeed, the figures in our database seem to be in accordance to this hypothesis: first, the average residual book value of assets was $\mathrm{R} \$ 320$ million, which implies that reorganizing firms had an average leverage of only $40 \%$. Second, the costs of 
the entire reorganization process seem low when compared to both total debt and residual book value: some collected reports indicate that this number is approximately $\mathrm{R} \$ 500$ thousand, which represents only $0.2 \%$ of residual book value and $0.4 \%$ of total debt. In this sense, in case of working capital mismanagement, as revealed by several financial statements we had access to, a reorganization filing seems to be a relatively cheap strategy.

The reorganization approval rate for our sample is $78 \%$, which is comparable to the $75 \%$ rate for Canada demonstrated by Fisher and Martel (1995), although the authors' data refer to the 1980s. Despite the high approval rate, only one in four companies survives the reorganization process in Brazil. In the United States, this proportion falls to only one in eight.

The approved plans required a larger haircut for secured creditors than the plans that were not approved (43\% versus 39\%), while the contrary holds for unsecured creditors (42\% versus 52\%). On average, the required waiting and amortization periods were longer for the approved plans, regardless of creditor class. The fact that the average haircut is similar for both classes of creditors is contrary to international evidence demonstrating that secured creditors fare relatively well in formal bankruptcies in countries such as the United States or the United Kingdom (Davydenko \& Franks, 2006; Franks \& Sussman, 2005).

Finally, Table 6 presents information regarding the frequency of certain events during the reorganization process. Sales of productive units to repay debt occurred $23 \%$ of the time, which indicates the use of merger and acquisition activities after reorganization approval. Gilson, Hotchkiss and Osborn (2015) argue that the use of merger and acquisition (M\&A) activities during bankruptcy proceedings blurs the traditional distinctions between reorganization and liquidation. Debt conversion occurred in only $6 \%$ of the sample.

Table 6

\section{Frequency of events during reorganizations}

\begin{tabular}{lc}
\hline Event & Frequency \\
\hline Capital subscription, raising capital or spin-off & $13 \%$ \\
Debt conversion & $6 \%$ \\
Debt issue & $5 \%$ \\
Share buyback & $1 \%$ \\
Productive unit sale & $23 \%$ \\
Creditor as a special partner* & $19 \%$ \\
\hline
\end{tabular}

Note. *By Special partner, we mean creditors who agree to better conditions for debt payment and/or offer new lines of credit. 


\section{Bargaining power}

Our first analysis regarding bank behavior consists of analyzing requests from bank creditors. The most frequent interventions were the bank requesting different payment conditions (7.8\%) and bank disagreement with the listed credit or presenting a challenge $(3 \%)$. All of the other interventions had a frequency of $1 \%$ or less. Large banks made two-thirds of these requests, which may indicate their negotiating power.

To better understand the banks' power empirically, we calculated a debt concentration index (DCI), which is similar to the Herfindahl index. The Herfindahl index goes from zero to one and is traditionally used to assess the amount of competition among firms in a certain industry. Higher values indicate more monopolistic markets. Here, we use it as a measure of the competition between banks during a certain reorganization case. The formula is:

$$
D C I=\sum_{i=1}^{n}{s_{i}}^{2}
$$

For each reorganization process, $s_{i}$ measures the proportion of the total debt held by each bank involved in the negotiation. We do so because some authors argue that debt dispersion can often lead to coordination failures (Bolton \& Scharfstein, 1996; Franks \& Sussman, 2005). As expected, the average DCI for secured debt is 0.7 , while that for unsecured debt is 0.45 . Because senior debt is more concentrated than unsecured debt in practice, this result suggests that senior bank creditors are able to agree to terms more easily than unsecured bank creditors can. In fact, the correlation between the average debt concentration and the plan approval rate is minus thirteen percent $(-13 \%)$.

\section{The impact of conflict between creditor classes}

Our second analysis of bank behavior consists of observing cases in which a conflict existed between the unsecured and secured bank creditors, which represents $16 \%$ of the sample, or 20 cases. In general, studies indicate that conflict between secured and unsecured creditors can significantly impact the outcome of a reorganization process (Ayotte $\&$ Morrison, 2009; Jenkins \& Smith, 2014; Longhofer \& Peters, 2004). Nevertheless, empirical analysis of this conflict is rather scarce. While the average approval rate for the entire sample is $80 \%$, for cases in which the secured and unsecured lenders disagree, this value falls to $75 \%$.

Ayotte and Morrison (2009) argue that when senior creditors are oversecured, i.e., when their claims are worth less than the value of the firm's assets, cases are more likely to result in liquidation, while the opposite holds when they are undersecured. In these cases, "creditor conflict is likely to be most pronounced" (p. 514). To see if this holds for our cases, we calculate the senior bank debt to residual value ratio, which averages 0.28 for the entire sample. Using a total senior debt/asset valuation ratio, the average value is 0.42 . Both figures indicate that senior 
creditors are oversecured. This result contrasts with Ayotte and Morrison's argument, as our average reorganization approval ratio is $78 \%$.

In the conflict cases, bank debt represented a much lower percentage of the total debt when compared to the no conflict cases (20\% versus almost $100 \%)$. Another finding that drew our attention was that the residual book value for the conflict cases was, on average, 19 times higher than that for the no conflict cases.

Regarding haircuts, senior creditors had an average haircut of $24.75 \%$ in conflict cases, whereas for junior bank creditors, the haircut was $32.42 \%$, which suggests that conflict is associated with a greater haircut for junior creditors and indicates that senior bank creditors may fare relatively well in these negotiations. The senior-to-junior ratio, which is the total amount of secured debt divided by the total amount of unsecured debt, was 2.6x for the entire sample and 1.0x for the conflict cases. This means that, on average, when there was a conflict, the amount of unsecured debt was almost the same as that of secured debt, which indicates conflict is indeed more likely to occur.

Baird and Morrison (2001) model the shutdown decision as a real option. We combine their ideas with Ayotte and Morrison's (Table 7) to determine whether this approach yields additional insights. We define a conflict between bank creditors if they reach no agreement during creditors' meetings, that is, if their votes differ. To classify whether creditors are in or out of the money, we calculate the debt to residual value ratio. We had information about residual book value for 58 companies. Creditors are in the money or able to exercise their option when that ratio is less than 1 (i.e., when their debt value is lower than the residual book value) and are out of the money otherwise.

Table 7

Reorganization as the exercise of a real option

\begin{tabular}{lccccc}
\hline & Conflict & \multicolumn{3}{c}{ No conflict } \\
\cline { 2 - 5 } & Approved & Rejected & Approved & Rejected \\
Senior bank debt/residual book value & 0.27 & 1.10 & 1.19 & 0.58 \\
Junior bank debt/residual book value & 0.51 & 2.33 & 10.87 & 4.09 \\
\hline
\end{tabular}

Note. This table presents the total debt/book residual value ratio for both creditor classes. Creditors are in the money if the ratio is equal or smaller than 1. For the computation of the senior debt ratio, we subtract the amount of labor debt, as workers have priority in payment according to the Brazilian bankruptcy code. For the computation of the junior debt ratio, we subtract the amount of senior debt for the same reason. The sample contains 125 cases, and conflict occurs in 20 of them.

In the cases when conflict existed and plans were approved, both bank creditor classes were deep in the money, which justifies the struggle between the parties: the portion to be distributed among creditors may be a subject of further discussion, as these companies have a residual book value much smaller than the sample average. In other words, if the company were liquidated at its residual book value, both groups would be able to receive the total amount of their credits without suffering any haircut. In fact, these are the only cases in which junior bank creditors are in the money. These findings are in line with Ayotte and Morrison's (2009) argument that when 
creditors holding collateral are overinsured (that is, their debt amount represents a smaller portion than the residual value of the company), conflict is more likely to occur.

In contrast, when plans were approved but there was no conflict, junior banks were so out of the money (10.87) that a conflict did not seem justifiable, as their expectation of recovery was minimal. In these cases, companies were significantly more leveraged. Nevertheless, the reorganization was approved, possibly because senior creditors were only slightly out of the money and had some expectation of credit recovery. The approval of such reorganizations may be an indication of inefficiency in the reorganization process, as these highly leveraged companies are less likely to recover from financial distress. Unfortunately, we do not have financial statement figures to offer additional analysis on this topic.

\section{Hypothesis tests - parametric and nonparametric average tests}

To understand how conflict between bank creditors impacts the outcome of reorganizations, we used parametric and nonparametric average tests to determine whether there is any difference between the cases in which bank creditors disagreed and those in which they reached common ground. Table 8 presents the parametric average tests for the variables we collected. For all the tests, our null hypothesis is that there is no difference between the groups (conflict versus no conflict).

Table 8

\section{Parametric average tests}

\begin{tabular}{lcccc}
\hline Variables & $\begin{array}{c}\text { Average - } \\
\text { conflict }\end{array}$ & $\begin{array}{c}\text { Average - No } \\
\text { conflict }\end{array}$ & T test & Conclusion \\
\hline Number of bank creditors & 8.00 & 6.63 & 0.35 & Confirmed \\
\hline Total debt & $\mathrm{R} \$ 82.09$ & $\mathrm{R} \$ 90.03$ & 0.00 & Confirmed \\
\hline Labor debt/total debt & $3.51 \%$ & $2.77 \%$ & 4.76 & Rejected \\
\hline Senior bank debt/total debt & $15.08 \%$ & $8.78 \%$ & 7.90 & Rejected \\
\hline Junior bank debt/total debt & $31.65 \%$ & $35.64 \%$ & -1.02 & Confirmed \\
\hline Haircut - senior debt & $24.75 \%$ & $10.90 \%$ & 10.40 & Rejected \\
\hline Haircut - junior debt & $32.42 \%$ & $26.52 \%$ & 4.71 & Rejected \\
\hline Amortization - senior debt ${ }^{3}$ & 91 months & 44 months & 0.11 & Confirmed \\
\hline Amortization - junior debt ${ }^{3}$ & 92 months & 99 months & -0.01 & Confirmed \\
\hline Waiting Period - senior debt ${ }^{3}$ & 21 months & 7 months & 0.45 & Confirmed \\
\hline${\text { Waiting Period }- \text { junior debt }{ }^{3}}^{\text {Debt conversion }}{ }^{1}$ & 20 months & 14 months & 0.16 & Confirmed \\
\hline Share repurchase & $0.00 \%$ & $7.77 \%$ & -5.26 & Rejected \\
\hline
\end{tabular}

Continues 


\section{Table 8 (continued)}

\begin{tabular}{lcccc}
\hline Variables & $\begin{array}{c}\text { Average - } \\
\text { conflict }\end{array}$ & $\begin{array}{c}\text { Average - No } \\
\text { conflict }\end{array}$ & T test & Conclusion \\
\hline New debt issue $^{1}$ & $0.00 \%$ & $5.83 \%$ & -5.15 & Rejected \\
\hline Productive unit sale $^{1}$ & $15.00 \%$ & $23.30 \%$ & -1.99 & Rejected \\
\hline Corporate restructuring $^{1}$ & $20.00 \%$ & $11.65 \%$ & 3.05 & Rejected \\
\hline Partner lenders, $^{2}$ & $25.00 \%$ & $17.48 \%$ & 2.03 & Rejected \\
\hline
\end{tabular}

Note. This table presents parametric average tests, with the sample grouped by the existence of conflict between bank creditors. The sample contains 125 cases, and conflict occurs in 20 of them. The results are reported for a 95\% confidence interval.

${ }^{1}$ As a proportion of the total number of reorganization cases. ${ }^{2}$ Partner Lenders are those willing to offer new lines of credit to the company in case the reorganization is granted. ${ }^{3}$ In months.

First, the average test for the ratio of senior bank debt to total debt is significant, which indicates a difference between the groups. This result is in line with the findings of the more traditional bankruptcy studies, which suggest that senior creditors have more bargaining power during reorganization negotiations (Ayotte $\&$ Morrison, 2009). Second, the tests demonstrate that there is a significant difference between the groups in terms of the amount of labor debt in relation to the total debt involved in the conflict cases. In addition to representing a higher percentage of total debt, we verify that in cases of conflict, companies had a much smaller residual book value. Due to discrepancy of data, however, we cannot conclude that labor debt imposes negotiation barriers.

Our third highlight concerns the interest rate and haircut offered to different groups of bank creditors, as both differences are statistically significant (with 95\% confidence). These results show that, on average, bank creditors with secured and unsecured guarantees received larger haircuts in cases where there was conflict. Interestingly, the interest rate offered to secured bank creditors was greater in cases where there was a conflict.

Contrary to the results found by Brunner and Kahnen (2008), the number of banks involved does not seem to be associated with the existence of conflicts between banks, since we did not find a significant difference between the samples. In fact, the correlation between the number of banks and the existence of conflict is low, at $12.63 \%$. However, the number of banks may be correlated to the vote of a bank creditor. To provide additional insights on this topic, we include the number of bank creditors in our probit and logit regressions.

Although there is no statistically significant difference for the waiting period, it is interesting to note that in cases where there was a conflict, the average waiting period for both classes was approximately 20 months, whereas for cases in which there was no conflict, the waiting period was significantly reduced.

Finally, there was a statistically significant difference for the sale of productive units, which occurred in $15 \%$ of the conflict cases, on average, and in $23 \%$ of the cases in which there was no conflict. Debt conversion, share repurchase or new debt issues occurred only in cases in which there was no conflict. The nonparametric tests support the null hypothesis that there is no 
significant difference between the groups (conflict versus no conflict). Table 9 reports the Wilcoxon test results (Mann-Whitney). Most tests show that there is no difference in means between the cases in which there was conflict and those without conflict except for the variable number of banks.

Table 9

\section{Nonparametric average tests}

\begin{tabular}{|c|c|c|}
\hline Variables & $Z$ test & Prob $|z|>Z$ \\
\hline Number of bank creditors & -2.12 & 0.03 \\
\hline Total debt & -0.23 & 0.81 \\
\hline Labor debt/total debt & -0.82 & 0.41 \\
\hline Senior bank debt/total debt & 0.59 & 0.55 \\
\hline Junior bank debt/total debt & 0.62 & 0.52 \\
\hline Haircut - senior debt & -0.45 & 0.64 \\
\hline Haircut - junior debt & -1.21 & 0.22 \\
\hline Amortization - senior debt ${ }^{3}$ & 1.24 & 0.21 \\
\hline Amortization - junior debt ${ }^{3}$ & 1.48 & 0.13 \\
\hline Waiting period - senior debt $^{3}$ & -0.78 & 0.43 \\
\hline Waiting period - junior debt ${ }^{3}$ & -1.42 & 0.15 \\
\hline Debt conversion ${ }^{1}$ & 1.28 & 0.19 \\
\hline Share repurchase ${ }^{1}$ & 0.44 & 0.65 \\
\hline New debt issue ${ }^{1}$ & 1.10 & 0.27 \\
\hline Productive unit sale ${ }^{1}$ & 0.81 & 0.41 \\
\hline Corporate restructuring ${ }^{1}$ & -1.01 & 0.31 \\
\hline Partner lenders, ${ }^{2}$ & -0.78 & 0.43 \\
\hline
\end{tabular}

Note. This table reports the nonparametric Wilcoxon average test, with the sample grouped by the existence of conflict between bank creditors. We assume the null hypothesis that there is no difference between the groups. The sample contains 125 cases, and conflict occurs in 20 of them.

${ }^{1}$ As a proportion of the total number of reorganization cases. ${ }^{2}$ Partner Lenders are those willing to offer new lines of credit to the company in case the reorganization is granted. ${ }^{3}$ In months.

\section{Bank size and reorganization approval}

In this subsection, we analyze whether the size of a bank has any relationship with the approval rate of reorganization filings. We used the Brazilian Central Bank's 2017 classification of banks. This segmentation divides banks into five main categories and aims to discipline prudential regulation of financial institutions according to size, international activity and risk profile. The first segment, S1, includes banks whose size is equal to or greater than $10 \%$ of GDP, or which are internationally active. Segment S2 is composed of institutions whose size represents between $1 \%$ and $10 \%$ of GDP. S3 relates to institutions whose size represents something between $0.1 \%$ and $1 \%$ of GDP. S4 institutions have a size that represents less than $0.1 \%$ of GDP. Finally, S5 segment relates to credit-cooperatives and nonbank institutions that have a simplified risk profile. 
As previously mentioned, our database contains a total of 108 banks. Thirty-four of these banks were not classified, either because they were extinct or merged with another institution. We use this classification to divide banks into three main categories: large banks ( $\mathrm{S} 1$ segment), medium banks (S2 and S3 segments) and small banks (S4 and S5 banks). Furthermore, we also divided banks between private and public. According to this classification, our sample has 10 large banks, 29 medium banks and 34 small banks. For each one, we calculated its debt proportion, which is how much its debt represents the total debt of the company that filed for reorganization.

Contrary to our expectations, average tests indicate that the proportion of bank debt is not significantly different for large banks $(t=0.8015)$, neither is the bank debt to asset ratio $(t=0.3967)$. Appendix illustrates how the approval rate changes depending on debt proportion. The average approval rate for large banks is larger than the approval rate for medium banks (60\% vs. 43\%). While the average debt proportion for large banks is $6 \%$, for medium banks it is larger (10\%). BNDES was only involved in two cases and voted in favor of the reorganization plan in both of them. Banco do Brasil and Bradesco have a similar approval rate (40\% and $42 \%$, respectively). Banrisul and Itaú are the banks with the highest approval rate (66\% and 59\%, respectively). Caixa, on the other hand, voted for approval in only $25 \%$ of the cases.

With respect to medium banks, Mercantil, Safra Daycoval were creditors in 8, 7 and 6 filings, respectively. The approval rate for these banks is higher than that of large banks, on average $(62 \%$, $66 \%$ and $83 \%$, respectively), and the debt proportion ranges from $6 \%$ to $10 \%$. Regarding small banks, we highlight HSBC and Industrial. The approval rates for these banks was $40 \%$ and 50\%, respectively. When we divide banks between private and public, there does not seem to be a relevant difference in terms of behavior, although private banks are involved in a much larger number of reorganization cases. While the average approval rate for private banks is $56 \%$, for public banks it is $54 \%$. The debt proportion is $7 \%$ and $4 \%$, respectively.

There were only 4 cases in which the debt proportion of the bank was larger than $10 \%$. One of them was related to BVA, a large bank that had $12 \%$ of total debt and approved the plan. Pine, a medium bank, had an average debt proportion of 14\% in 2 cases, but voted against the reorganization in both of them. Regarding small banks, ABN had an average debt proportion of $66 \%$ in 2 cases; it approved one of them and opposed the other. Finally, Potencial, another small bank, had a debt proportion of $22 \%$ in a case in which it voted favorably.

\section{Regression Analysis}

The purpose of this section is to provide further evidence about the relationship between the variables under investigation rather than to infer causal relations due to the very nature of our data. Because we do not have access to balance sheet data, for instance, we cannot account for endogeneity concerns such as omitted variable bias. However, as we mention throughout the text, the main purpose of this study is to describe a dataset that has not yet been explored in the literature. 
We denote bank creditors by $i$ and companies by $j$. Our standard model is the following:

$$
\begin{aligned}
\text { Vote }_{i, j}=\alpha_{0}+ & \alpha_{1} \ln \left(\text { QtyBanks }_{j}\right)+\alpha_{2} \text { QtyBanks }_{j}^{2}+\alpha_{3} \ln \frac{\text { BankDebt }_{i}}{\text { Asset }_{j}} \\
& +\alpha_{3} \ln \left(\text { Age }_{j}\right)+\alpha_{4} \text { Age }_{j}^{2}+\alpha_{5} \text { Large }_{i}+u_{i, j}
\end{aligned}
$$

The first variable represents the natural logarithm of the number of bank creditors involved in the reorganization, and the second is the square of the number of bank creditors. The third variable indicates how much debt bank $i$ has in the reorganization. Ln(Age) is the natural logarithm of the number of years of existence of the firm under reorganization, and we also include the square of this variable. The use of the square of the variables QtyBanks and Age is useful to indicate whether there is a concave relationship between the vote of a bank and these characteristics. Finally, Large is a dummy indicating whether the bank is large. We used probit and logit specifications to understand which factors are associated with bank creditors voting in favor of a reorganization.

Our models also include controls at the year and state level to account for possible heterogeneities that could impact a creditor's vote in a reorganization process. The inclusion of sector controls and other covariates mentioned in the text is not feasible because of multicollinearity. Finally, it is important to note that due to the endogeneity concerns previously noted, we cannot include the existence of conflict in our regression analysis. As we define conflict as the difference between bank creditor classes' decisions, including a dummy for conflict would be equivalent to regressing vote on vote.

\section{Results}

The results are reported in Table 10. Model 1 is analog to equation (1) for the logit specification, and Model 2 is analog to equation (1) for the probit specification. Models 3 and 4 include year controls for the logit and probit specifications, respectively, and Models 5 and 6 include state controls. 
Table 10

Regression results

\begin{tabular}{|c|c|c|c|c|c|c|}
\hline & (1) & (2) & (3) & (4) & (5) & (6) \\
\hline Variables & Vote & Vote & Vote & Vote & Vote & Vote \\
\hline \multirow[t]{2}{*}{ In_qtybanks } & $1.916^{*}$ & $1.129^{\star \star}$ & 1.112 & 0.603 & 1.941 & 1.186 \\
\hline & $(0.980)$ & $(0.531)$ & (1.385) & $(0.712)$ & (1.683) & $(1.044)$ \\
\hline \multirow[t]{2}{*}{ Qtybanks² $^{2}$} & $-0.0272^{* * *}$ & $-0.0163^{* * *}$ & -0.0102 & -0.00591 & -0.00784 & -0.00502 \\
\hline & $(0.00884)$ & $(0.00481)$ & $(0.0150)$ & $(0.00824)$ & $(0.0226)$ & $(0.0137)$ \\
\hline \multirow[t]{2}{*}{ bankdebt_asset_ratio } & -0.409 & -0.290 & -0.0131 & -0.155 & 0.730 & 0.469 \\
\hline & (1.709) & $(1.016)$ & $(1.869)$ & (1.105) & (1.951) & (1.188) \\
\hline \multirow[t]{2}{*}{ In_age } & $1.568^{\star \star \star}$ & $0.947^{\star \star *}$ & 0.712 & 0.426 & $2.001^{* * *}$ & $1.199^{\star * *}$ \\
\hline & $(0.477)$ & $(0.278)$ & $(0.724)$ & $(0.433)$ & $(0.603)$ & $(0.341)$ \\
\hline \multirow[t]{2}{*}{$\mathrm{Age}^{2}$} & $-0.000227^{\star *}$ & $-0.000135^{\star *}$ & 0.000388 & 0.000218 & $-0.000405^{\star *}$ & $-0.000242^{\star *}$ \\
\hline & $(0.000107)$ & $(6.28 \mathrm{e}-05)$ & $(0.000341)$ & $(0.000194)$ & $(0.000179)$ & $(0.000104)$ \\
\hline \multirow[t]{2}{*}{ large } & -0.517 & -0.292 & -0.506 & -0.284 & -0.390 & -0.204 \\
\hline & $(0.538)$ & $(0.315)$ & $(0.566)$ & $(0.341)$ & $(0.570)$ & $(0.335)$ \\
\hline \multirow[t]{2}{*}{ Constant } & $-5.871^{* * *}$ & $-3.503^{* * *}$ & 12.21 & 2.437 & $-8.309^{* * *}$ & $-5.004^{* * *}$ \\
\hline & $(2.160)$ & $(1.220)$ & (2.402) & $(308.1)$ & (2.934) & $(1.770)$ \\
\hline Observations & 92 & 92 & 89 & 89 & 82 & 82 \\
\hline Pseudo R-squared & 0.2398 & 0.2420 & 0.2989 & 0.2988 & 0.2179 & 0.2177 \\
\hline Logit & Yes & No & Yes & No & Yes & No \\
\hline Probit & No & Yes & No & Yes & No & Yes \\
\hline Bank Size Controls & Yes & Yes & Yes & Yes & Yes & Yes \\
\hline Year Controls & No & No & Yes & Yes & Yes & Yes \\
\hline State Controls & No & No & No & No & Yes & Yes \\
\hline
\end{tabular}

Note. Standard errors in parentheses.

${ }^{* * *} p<0.01,{ }^{* *} p<0.05,{ }^{*} p<0.1$

Models 1 and 2 indicate that the relationship between voting in favor of a reorganization and the number of bank creditors involved is concave: when considering the number of banks involved, the likelihood of a bank voting in favor of a reorganization rises at decreasing rates. This is evidence of a coordination problem between creditors and in is line with what we verified using descriptive statistics and also in line with Brunner and Kahnen (2008). Additionally, Models 1 and 2 indicate that banks tend to favor reorganization of older companies, although this relationship is also concave. This finding might indicate that creditors will prefer to approve the reorganization of mature companies, although companies that exist for too long may not be able to reinvent themselves, so creditors will be better off when they are liquidated. When we use year controls, most of the significance of coefficients disappears, which indicates the cyclical component of the process of corporate reorganizations. 
Our estimations also demonstrate that bank size is not associated with an increased likelihood of favoring a reorganization, nor is the proportion of bank debt. Altogether, these results demonstrate that seniority plays a much larger role in bankruptcy than the size of a bank creditor relative to the remaining creditors.

Regarding the quality of estimation, postestimation analysis indicates that $65.22 \%$ of our observations are correctly classified. The use of the iuprobit command in Stata also indicates that there are no endogenous regressors, which means the probit specification is adequate. Nevertheless, because we could not obtain balance sheet data, we cannot account for all sources of endogeneity that this model might have. Again, our purpose with these regressions is to provide further evidence of the relationship between the variables under investigation rather than to describe causal relationships.

Contrary to our expectations, the proportion of debt of a bank creditor is not significant to explain the vote. This might indicate that idiosyncratic reasons are much more important in determining the outcome of a reorganization request.

\section{Conclusion}

The goal of this study was to analyze how bank creditors respond to corporate reorganization filings. We hand collected data on 125 reorganization filings in Brazil from 2006 to 2016. The methodology for this study consisted of detailed descriptive statistics as well as average tests, both parametric and nonparametric. We use these tests to identify which factors are associated with the conflict between creditor classes. We also used logit and probit specification to understand which factors were associated with banks voting in favor of reorganizations. We offer insights into the role of senior creditors during these processes because the literature demonstrated mixed evidence on the topic. We contribute to the literature by analyzing the role of bank creditor seniority on reorganization outcomes of companies that exhibit a higher level of information asymmetry regarding their financial statements and by exploring which factors are associated with conflicting creditor decisions in the context of emerging economies and creditor-oriented bankruptcy regimes.

In general, our analysis demonstrates that senior creditors have come to dominate the reorganization process, as some of the recent literature on bank creditor behavior proposes. Specifically, we provide insights into the conflict between bank creditor classes, a topic with scarce evidence in the literature. If we re-examine the bargain as the exercise of a real option, it is clear that conflict exists when bank creditors' classes were in the money. In line with the literature, we also demonstrate that the number of creditors involved is significant to explaining creditor's behavior. We find a concave relationship between favorable votes and the number of bank creditors involved in a reorganization and between favorable votes and a company's age. Additionally, the proportion of a bank creditor's debt is not significant for explaining their vote.

To deepen our analysis, future research should include financial statement information and data on post-reorganization performance. 


\section{Contributions}

$1^{\text {st }}$ author: discussion of the concept and design of this study; responsible for hand-collecting the information on these filings; responsible for the writing of the manuscript; responsible for implementing the changes resulting from discussions, as well as for the empirical analysis.

$2^{\text {nd }}$ author: discussion of the concept and design of this study; responsible for the writing of the manuscript.

$3^{\text {rd }}$ author: discussion of the concept and design of this study; responsible for gathering the initial documents for analysis.

As per the discussion and final approval of the paper, we had a total of 8 rounds in which all three authors participated.

\section{References}

Allen, F., Chui, M. K. F., \& Maddaloni, A. (2008). Financial structure and corporate governance in Europe, the USA, and Asia. In X. Freixas, P. Hartmann, P., \& Mayer, C. (Eds.). Handbook of European financial markets and institutions (Vol.1, Chapter 1, pp. 31-68). New York, NY: Oxford University Press

Annabi, A., Breton, M., \& François, P. (2012). Resolution of financial distress under chapter 11. Journal of Economic Dynamics and Control, 36(12), 1867-1887. https://doi.org/10.1016/j.jedc.2012.06.004

Araujo, A., \& Funchal, B. (2005). Past and future of the bankruptcy law in Brazil and Latin America. Ensaios Econômicos, 599, 1-70. Retrieved from https://pdfs.semanticscholar.org/ab30/a5a34aab7c9992aaab1fe2c51efe21bb9203.pdf

Asquith, P., Gertner, R., \& Scharfstein, D. (1994). Anatomy of financial distress: An examination of junk bond issuers. Quarterly Journal of Economics, 109(3), 625-658. https://doi.org/10.2307/2118416

Ayotte, K., \& Morrison, E. (2009). Creditor control and conflict in chapter 11. Journal of Legal Analysis, 1(2), 511 551. https://doi.org/10.1093/jla/1.2.511

Bae, K-H., \& Goyal, V. K. (2009). Creditor rights, enforcement, and bank loans. The Journal of Finance, 64(2), 823860. https://doi.org/10.1111/j.1540-6261.2009.01450.x

Baird, D. G., \& Morrison, E. R. (2001). Bankruptcy decision making. Journal of Law, Economics, $\mathcal{G}$ Organization, 17(2), 356-372. https://doi.org/10.1093/jleo/17.2.356

Bebchuk, L. A. (2002). Ex ante costs of violating absolute priority in bankruptcy. The Journal of Finance, 57(1), 445460. https://doi.org/10.1111/1540-6261.00427

Bebchuk, L. A., \& Chang, H. F. (1992). Bargaining and the division of value in corporate reorganization. Journal of Law, Economics $\mathcal{E}$ Organization, 8(2), 253-279. https://doi.org/10.3386/t0097

Bolton, P., \& Scharfstein, D. (1996). Optimal debt structure and the number of creditors. Journal of Political Economy, 104(1), 1-25. http://www.jstor.org/stable/2138957

Branch, B., \& Ray, H. (2007). Bankruptcy investing: How to profit from distressed companies. Washington, DC: Beard Books

Brunner, A., \& Krahnen, J. P. (2008). Multiple lenders and corporate distress: Evidence on debt restructuring. The Review of Economic Studies, 75(2), 415-442. https://doi.org/10.1111/j.1467-937X.2008.00483.x

Bulow, J. I., \& Shoven, J. B. (1978). The bankruptcy decision. The Bell Journal of Economics, 9(2), 437-456. https://doi.org/10.2307/3003592

Chen, Y., Weston, J. F., \& Altman, E. I (1995). Financial distress and restructuring models. Financial Management, 24(2), 57-75. https://doi.org/10.2307/3665535 
Claessens, S., Djankov, S., \& Klapper, L. (2003). Resolution of corporate distress in East Asia. Journal of Empirical Finance, 10(2), 199-216. https://doi.org/10.1016/S0927-5398(02)00023-3

Copetti, T. (2017, January 4). Recuperação judicial fecha 2016 com recorde. Retrieved from http://www.fenacon.org.br/noticias/recuperacao-judicial-fecha-2016-com-recorde-1377/

Davydenko, S. A., \& Franks, J. (2006). Do bankruptcy codes matter? A study of defaults in France, Germany and the UK. EFA 2005 Moscow Meetings Paper; ECGI - Finance Working Paper No. 89/2005; WFA 2005 Portland Meetings Paper; AFA 2005 Philadelphia Meetings Paper. http://dx.doi.org/10.2139/ssrn.647861

Eberhart, A. C., Moore, W. T., \& Roenfeldt, R. L. (1990). Security pricing and deviations from the absolute priority rule in bankruptcy proceedings. The Journal of Finance, 45(5), 1457-1469. https://doi.org/10.1111/j.1540. 6261.1990.tb03723.x

Fama, E. F. (1985). What's different about banks? Journal of Monetary Economics, 15(1), 29-39. https://doi.org/10.1016/0304-3932(85)90051-0

Fan, H., \& Sundaresan, M. (2000). Debt valuation, renegotiation, and optimal dividend policy. Review of Financial Studies, 13(4), 1057-1099. https://doi.org/10.1093/rfs/13.4.1057

Fisher, T. C. G., \& Martel, J. (1995). The creditors' financial reorganization decision: New evidence from Canadian data. Journal of Law, Economics $\mathcal{E} \quad$ Organization, $11(1), \quad 12-126$. https://doi.org/10.1093/oxfordjournals.jleo.a036862

Franken, S. (2004). Creditor- and debtor-oriented corporate bankruptcy regimes revisited. European Business Organization Law Review, 5(4), 645-676. https://doi.org/10.1017/S1566752904006457

Franks, J., \& Sussman, O. (2005). Financial distress and bank restructuring of small to medium size UK companies. Review of Finance, 9(1), 65-96. https://doi.org/10.1007/s10679-005-2988-8

Franks, J. R., \& Torous, W. N. (1989). An empirical investigation of U.S. firms in reorganization. The Journal of Finance, 44(3), 747-769. https://doi.org/10.1111/j.1540-6261.1989.tb04389.x

Gertner, R., \& Scharfstein, D. (1991). A theory of workouts and the effects of reorganization law. The Journal of Finance, 46(4), 1189-1222. https://doi.org/10.1111/j.1540-6261.1991.tb04615.x

Gilson, S. C., Hotchkiss, E., \& Osborn, M. (2015). Cashing out: The rise of M\&A in bankruptcy [No. 15-057]. Harvard Business School Working Paper, Boston, MA, USA. http://dx.doi.org/10.2139/ssrn.2547168

Gilson, S. C., Hotchkiss, E. S., \& Ruback, R. S. (2000). Valuation of bankrupt firms. Review of Financial Studies, 13(1), 43-74. https://doi.org/10.1093/rfs/13.1.43

Gilson, S. C., \& Vetsuypens, M. R. (1994). Creditor control in financially distressed firms: Empirical evidence. Washington University Law Review, 72(3), 1005-1025. Retrieved from https://openscholarship.wustl.edu/law_lawreview/vol72/iss3/18

Hotchkiss, E. S., John, K., Mooradian, R. M., \& Thorburn, K. S. (2008). Bankruptcy and the resolution of financial distress. In B. E. Eckbo (Ed.), Handbook of empirical corporate finance (Vol. 2, Chapter 14, pp. 235-287). North Holland, Netherlands: Elsevier.

Jackson, T. H. (1982). Bankruptcy, non-bankruptcy entitlements, and the creditors' bargain. The Yale Law Journal, 91(5), 857-907. Retrieved from http://digitalcommons.law.yale.edu/ylj/vol91/iss5/1

James, C. (1995). When do banks take equity in debt restructurings? The Review of Financial Studies, 8(4), 1209-1234. https://doi.org/10.1093/rfs/8.4.1209

Jenkins, M., \& Smith, D.C. (2014). Creditor conflict and the efficiency of corporate reorganization. [Working Paper]. Social Science Research Network, Rochester, NY. http://dx.doi.org/10.2139/ssrn.2444700

Kirschbaum, D. (2009). A recuperação judicial no Brasil: Governança, financiamento extraconcursal e votação do plano (Tese de doutorado). Faculdade de Direito, Universidade de São Paulo, São Paulo, SP, Brazil. Retrieved from http://www.teses.usp.br/teses/disponiveis/2/2132/tde-03062011-104905/pt-br.php

Lei n. 11.101, de 9 de fevereiro de 2005. (2005). Regula a recuperação judicial, a extrajudicial e a falência do empresário e da sociedade empresária. Retrieved from http://www.planalto.gov.br/ccivil_03/_Ato20042006/2005/Lei/L11101.htm 
Li, D.D., \& Li, S. (1999). An agency theory of the bankruptcy law. International Review of Economics $\mathcal{E}$ Finance, 8(1), 1-24. https://doi.org/10.1016/S1059-0560(99)00002-7

Longhofer, S. D., \& Peters, S. R. (2004). Self-selection and discrimination in credit markets [Working Paper]. Social Science Research Network, Rochester, NY. http://dx.doi.org/10.2139/ssrn.118088

Ministério da Justiça. (2011). Recuperação judicial de empresas - Guia prático. Retrieved from http://cfa.org.br/wpcontent/uploads/2018/02/39arte_final_cartilha_16_WEB.pdf

Silva, V. A. B. (2015). Essays on corporate restructuring (Tese de doutorado). Escola de Administração de Empresas de São Paulo, Fundação Getulio Vargas, São Paulo, SP, Brasil. Retrieved from https://bibliotecadigital.fgv.br/dspace/handle/10438/15057

Weiss, L. A. (1990). Bankruptcy resolution: Direct costs and violation of priority of claims. Journal of Financial Economics, 27(2), 285-314. https://doi.org/10.1016/0304-405X(90)90058-8

Welch, I. (1997). Why is bank debt senior? A theory of asymmetry and claim priority based on influence costs. The Review of Financial Studies, 10(4), 1203-1236. https://doi.org/10.1093/rfs/10.4.1203

Westbrook, J. L. (2015). Secured creditor control and bankruptcy sales: An empirical view. University of Illinois Law Review, 2, 831-845. Retrieved from https://illinoislawreview.org/wp-content/ilrcontent/articles/2015/2/Westbrook.pdf

White, M. J. (1981). Economics of bankruptcy: Liquidation and reorganization [Salomon Brother Working Paper No. 239]. Salomon Brother Center for the Study of Financial Institutions, Graduate School of Business Administration, New York University, New York, NY.

\section{Authors}

\section{Mariana Oreng}

Fundação Getulio Vargas, Escola de Administração de Empresas de São Paulo Avenida Nove de Julho, 2029, 01313-902, São Paulo, SP, Brazil mariana.oreng@gmail.com

(iD) http://orcid.org/0000-0002-7266-6560

\section{Richard Saito}

Fundação Getulio Vargas, Escola de Administração de Empresas de São Paulo Avenida Nove de Julho, 2029, 01313-902, São Paulo, SP, Brazil

rsaito@finenge.com

iD https://orcid.org/0000-0002-9512-9071

\section{Vinicius A. B. Silva}

Fundação Escola de Comércio Álvares Penteado Av. da Liberdade, 532, 01502-001, São Paulo, SP, Brazil vinicius.brunassi@fecap.br

(iD https://orcid.org/0000-0002-1299-321X 


\section{APPENDIX}

\section{Bank size and reorganization approval}

This panel depicts the debt proportion each bank had on reorganization filings and how many cases in which it voted in favor of the reorganization, as proportion of the total.

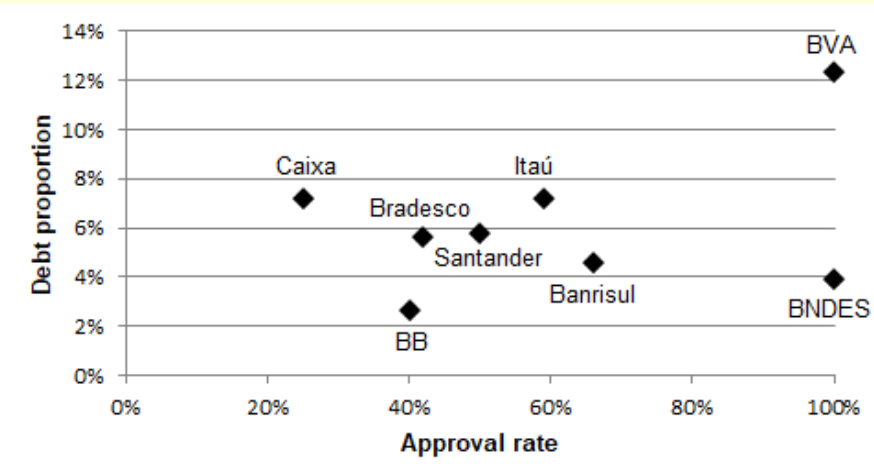

Figure A1. Large banks

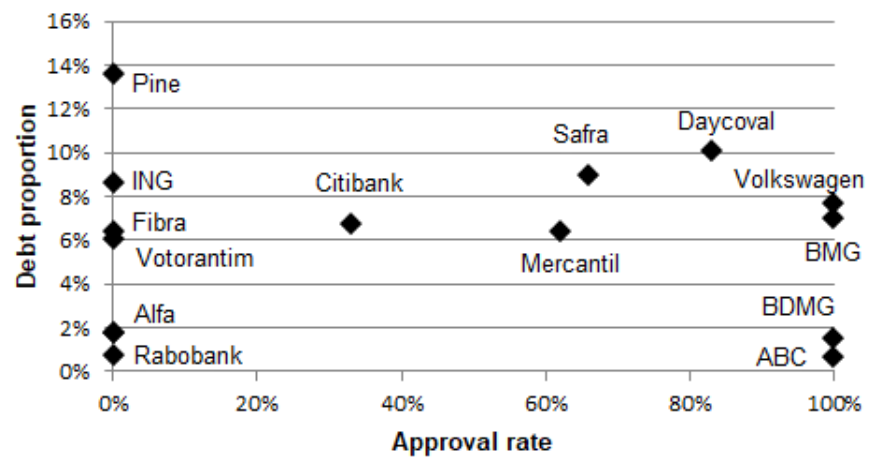

Figure A2. Medium banks

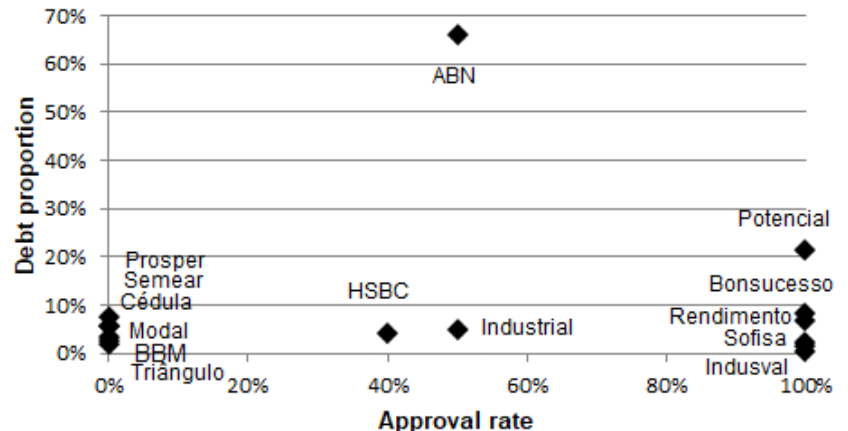

Figure A3. Small banks 